\title{
Complex segregation analysis of 1,792 cleft lip and palate families in South America: 1967-1997
}

\section{Análise de segregação complexa de $\mathbf{1 . 7 9 2}$ famílias com fenda lábio-palatina na América do Sul: 1967-1997}

\author{
Alexandre Rezende Vieira* \\ Paul Anthony Romitti** \\ Iêda Maria Orioli*** \\ Eduardo Enrique Castilla****
}

\begin{abstract}
Although several studies have demonstrated familial aggregation of nonsyndromic cleft lip with or without cleft palate $(\mathrm{CL} / \mathrm{P})$, its model of inheritance remains uncertain. We report the results of complex segregation analysis performed in South American families with a newborn affected with CL/P. Families of 1,792 consecutive newborns affected with CL/P and registered during the period 1967 to 1997 were studied. A model that did not include a major $l o-$ cus was the best-fitting model for $\mathrm{CL} / \mathrm{P}$ families. This result is in agreement with previous studies which showed a significant association of several putative susceptibility loci and CL/P, indicating that the genes involved in CL/P are likely to have only a very modest impact on disease risk.

DESCRIPTORS: Cleft palate; Craniofacial abnormalities; Abnormalities; Polygenic inheritance.
\end{abstract}

\begin{abstract}
RESUMO: Os estudos sobre fendas lábio-palatinas (FL/P) demonstram existir uma maior incidência do defeito nas famílias de afetados, mas seu modo de herança permanece indefinido. Esse trabalho apresenta os resultados de uma análise de segregação complexa realizada em 1.792 famílias sul-americanas que possuíam um recém-nascido com FL/P. Essas crianças foram registradas entre 1967 e 1997 e os nascimentos foram consecutivos. Um modelo sem um locus principal foi o que melhor se adequou às famílias de FL/P estudadas. Esse resultado está de acordo com estudos anteriores que mostraram uma significativa associação entre vários loci de suscetibilidade e FL/P, indicando que os genes relacionados com $\mathrm{FL} / \mathrm{P}$, isoladamente, contribuem pouco para o risco desse defeito.
\end{abstract}

DESCRITORES: Fissura palatina; Anormalidades craniofaciais; Anormalidades; Herança poligênica.

\section{INTRODUCTION}

It was generally accepted that cleft lip with or without cleft palate (CL/P) was inherited as a multifactorial trait ${ }^{8}$. However, this view has been challenged ${ }^{17}$ based on complex segregation analysis, which implicitly evaluated single major locus versus multifactorial threshold models of inheritance. It has been suggested that the familial aggregation pattern for CL/P is more consistent with a model in which liability is determined by a single major locus (which may or may not act against a background of multifactorial threshold inheritance) than it is with simple multifactorial threshold inheritance $^{19}$. However, as a whole, the results of such analyses are far from conclusive ${ }^{21,26}$.
The frequency of CL/P in South America is 1.1 per 1,000 births ${ }^{16}$ but there is indication that South American populations living at very high altitudes, including three capital cities located at more than 2,000 meters above sea level (Bogota, Colombia; La Paz, Bolivia; and Quito, Ecuador), altogether comprising more than 8 million inhabitants, have higher risk for craniofacial defects, including $\mathrm{CL} / \mathrm{P}^{10}$. Some investigations about inheritance of CL/P have been done in South American populations and they also indicate that there is no consensus as to whether a single gene model or a multifactorial model is better for CL/P. A multifactorial model for CL/P cases from ECLAMC (Latin American Collaborative Study of Congenital

\footnotetext{
*Post Doctoral Fellow, Department of Pediatrics; **Assistant Professor, Department of Epidemiology - University of Iowa.

***Full Professor, Department of Genetics, Federal University of Rio de Janeiro.

**** MD, Latin American Collaborative Study of Congenital Malformations (ECLAMC), Department of Genetics, Oswaldo Cruz Institute.
} 
Vieira AR, Romitti PA, Orioli IM, Castilla EE. Complex segregation analysis of 1,792 cleft lip and palate families in South America: 1967-1997. Pesqui Odontol Bras 2003;17(2):161-5.

Malformations) was suggested based on calculations of the frequency of the malformation in sibs and its frequency in the general population, as well as separately for those of male and female probands ${ }^{18}$. Studies done in Chile pointed to the presence of a major gene effect with reduced penetrance ${ }^{4,23}$. A Brazilian study suggested a two major loci model for CL/ $\mathrm{P}^{1}$. ECLAMC has built an infrastructure to collect, handle and analyze biological samples from cleft families ${ }^{22}$. A better understanding of the mode of inheritance of $\mathrm{CL} / \mathrm{P}$ and the confirmation of a major gene model in this population would lead us to molecular studies using a candidate gene approach.

To take advantage of a large sample from ECLAMC, in the present analysis we evaluate the pattern of inheritance of CL/P in a South American population.

\section{MATERIALS AND METHODS}

Data on $\mathrm{CL} / \mathrm{P}$ were provided by ECLAMC. ECLAMC, a multinational birth defects registry in South America, has operated since 1967 and utilizes 70 hospitals and volunteer physicians to collect data on approximately 150,000 births per year (4 million since 1967) .

Briefly, all liveborns and stillborns having a birth defect are recorded. CL/P is uniformly classified according to a manual containing an accurate description of the malformation. The manual also permits further categorization of CL/P into various subtypes and contains the information necessary to complete the registration form for the ECLAMC study. Information regarding the infant, pregnancy, parents, and family history is available from the registration form completed at birth by a member of the medical staff (usually a pediatrician). In particular, the presence of $\mathrm{CL} / \mathrm{P}$ in the first (sibs and parents), second (aunts, uncles, half-siblings, and grandparents), and third (cousins and great-grandparents) degree relatives is recorded. A careful physical examination of the probands is performed by the physician; at a minimum, skeletal X-rays, chromosomal analysis and photography are carried out in cases of non-isolated $\mathrm{CL} / \mathrm{P}$. Physicians are requested to specify any other anomaly present in the child affected with $\mathrm{CL} / \mathrm{P}$; minor and major congenital malformations are described. The completed forms are then transmitted to the registry and coded and reviewed by a clinical geneticist. Furthermore, multiple sources of ascertainment were used to confirm re- gistrations, to add further information in order to define malformations, and to identify cases not registered at birth.

4,037 cases were identified having $\mathrm{CL} / \mathrm{P}$ along with other malformations or not. Subjects in this study consist of all newborns presenting with isolated CL/P ascertained in the ECLAMC during the period 1967 to 1997 for a total of $1,792 \mathrm{CL} / \mathrm{P}$ (1,059 males and 733 females) cases.

Segregation analysis using the logistic regressive model was applied to characterize the genetic component and the mode of inheritance of CL/P. The class A model ${ }^{7}$ was fitted using the REGD program from the Statistical Analysis for Genetic Epidemiology package (SAGE) (Case Western Reserve University, Cleveland, OH, USA) ${ }^{25}$. The parameters of the model were estimated by the method of maximum likelihood, which included type frequencies, baseline parameters ( $\beta \mathrm{AA}, \beta \mathrm{AB}, \beta \mathrm{BB})$, transmission probabilities ( $\tau \mathrm{AA}, \tau \mathrm{AB}, \tau \mathrm{BB}$ ), and residual familial effects including effects of parents and siblings. Sex was the covariate adjusted for in the model. Pedigrees were included in the study because the index case was affected with isolated cleft palate. The conditioned subset was designed to be the parents of the index case.

A major gene effect was assumed to result from segregation at a single locus having two alleles, A and $\mathrm{B}$, where allele $\mathrm{A}$ was associated with the affected state. We assumed random mating and Hardy-Weinberg equilibrium. The transmission parameter $\tau_{\mathrm{g}}$ is defined as the probability that a parent of type $g$ transmits allele A to its offspring. The transmission parameter is generally allowed to range from 0 to 1 . Under Mendelian transmission, $\tau(\mathrm{AA})=1, \tau(\mathrm{AB})=0.5, \tau(\mathrm{BB})=0$. The non transmitted model was fitted by setting the three transmission probabilities equal to the frequency of $\mathrm{A}[\tau(\mathrm{AA})=\tau(\mathrm{AB})=\tau(\mathrm{BB})]^{24}$.

A likelihood-ratio test (LRT) was used to select the most parsimonious model. The LRT statistic is calculated as minus twice the difference of the $\log _{\mathrm{e}}$ likelihood $(\operatorname{lnL})$ between the general and the restricted model and is distributed asymptotically as a chi-square with degrees of freedom equal to the difference in the number of parameters between two competing models. The LTR is based on a comparison of strictly hierarchical models (general transmission, non transmitted factor, single Mendelian gene and no major factor). In addition, the Akaike information criterion (AIC) was calculated for each model. The LRT is based on a comparison of strictly hierarchical models, but for those nonhi- 
Vieira AR, Romitti PA, Orioli IM, Castilla EE. Complex segregation analysis of 1,792 cleft lip and palate families in South America: 1967-1997. Pesqui Odontol Bras 2003;17(2):161-5.

erarchical models the best fitting model was considered to be the one with lowest value of the AIC. The AIC for any model is equal to $-2(\log$ likelihood) +2 (number of estimated parameters). The model with the smallest AIC is the most parsimonious of the best-fitting models for the data.

\section{RESULTS}

A total of $1,792 \mathrm{CL} / \mathrm{P}$ families were studied. Table 1 presents the distribution of CL/P cases in South America. Table 2 shows the distribution of subjects with CL/P by family size. Table 3 presents the results of the segregation analysis for $\mathrm{CL} / \mathrm{P}$. In the general model, we estimated 12 parameters for $\mathrm{CL} / \mathrm{P}$ and their standard deviations. The estimates of gene frequency, baseline parameters, and resi-

TABLE 1 - Distribution of cleft lip with or without cleft palate $(\mathrm{CL} / \mathrm{P})$ individuals across South American countries.

\begin{tabular}{l|rr|l}
\hline \hline Country & \multicolumn{2}{|c|}{ CL/P probands $(\%)$} & $\begin{array}{c}\text { Number of hospitals } \\
\text { (country regions covered) }\end{array}$ \\
\hline Argentina & 742 & $(41.4)$ & 54 (all country) \\
\hline Bolivia & 141 & $(7.9)$ & 3 (highlands and vale) \\
\hline Brazil & 251 & $(14.0)$ & 19 (southeast and northeast) \\
\hline Chile & 216 & $(12.1)$ & 8 (all country) \\
\hline Colombia & 25 & $(1.4)$ & 2 (Bogota city and Andes) \\
\hline Ecuador & 111 & $(6.2)$ & 2 (mountains and coast) \\
\hline Peru & 18 & $(1.0)$ & 2 (Lima city) \\
\hline Uruguay & 67 & $(3.7)$ & 7 (all country) \\
\hline Venezuela & 221 & $(12.3)$ & 5 (Caracas city, coast, \\
\hline Total & 1,792 & $(100.0)$ & \\
\hline \hline
\end{tabular}

TABLE 2 - Distribution of CL/P individuals across pedigrees.

\begin{tabular}{c|rcc|c}
\hline \hline $\begin{array}{c}\text { No. } \\
\text { affected/pedigree }\end{array}$ & \multicolumn{2}{|c|}{$\begin{array}{c}\text { No. of } \\
\text { pedigrees }(\%)\end{array}$} & $\begin{array}{c}\text { Pedigree size } \\
\text { range }\end{array}$ \\
\hline 1 & 1,504 & $(83.93)$ & $3-22$ \\
\hline 2 & 229 & $(12.78)$ & $4-26$ \\
\hline 3 & 51 & $(2.85)$ & $7-28$ \\
\hline 4 & 7 & $(0.39)$ & $9-17$ \\
\hline 5 & 1 & $(0.05)$ & 18 \\
\hline Total & 1,792 & $(100.0)$ & $3-28$ \\
\hline \hline
\end{tabular}

dual familial effects were all arbitrary. All other models were tested against this general model.

For $\mathrm{CL} / \mathrm{P}, 1,792$ pedigrees were included in the analysis. The non transmitted factor model was strongly rejected $\left(\chi^{2}=113.34, p<0.001\right)$, suggesting significant familial aggregation. The no major locus model provides a significantly better explanation of the data. It is the most parsimonious and has the smallest AIC value of the six models tested with approximately the same likelihood as the general model $\left(\chi^{2}=2.35, \mathrm{p}=0.5\right)$.

\section{DISCUSSION}

The mode of inheritance of CL/P has been investigated, and most studies demonstrated familial aggregation of nonsyndromic $\mathrm{CL} / \mathrm{P}^{21,26}$. However, there is no consensus as to which model best describes the mode of inheritance of CL/P. Potential models include a major susceptibility locus, a major autosomal dominant or recessive locus or a multigenic inheritance.

The validity of conclusions drawn from familial recurrence-pattern analysis is basically dependent on ascertainment ${ }^{11}$. Most of the studies collected data retrospectively from surgical records, including affected subjects from different geographical areas and born over a long time span. In fact, if ascertainment is incomplete, as it is in data from surgical records where usually only the more severe cases are registered, the analysis could be distorted. Also, studies based on a limited number of families could be biased because of the inclusion of a high proportion of multiplex families.

Our sample is based on a large number of consecutive births, with quality control to detect associated anomalies and malformation syndromes. Also a very accurate description and diagnostic definition of the malformation (nonsyndromic and not associated with other anomalies) is obtained for ECLAMC. However to be able to study a very large data set, a large time span was required. ECLAMC collects data from most of the South America countries (Table 1), and geographic differences between these countries might exist. This could decrease the probability of detecting an environmental effect, if it exists.

The present study is comparable to the study of inheritance of CL/P in Italy ${ }^{12}$. The ECLAMC and North East Italy (NEI) and the Region Emilia Romagna (IMER) registries work using the same approach. The ECLAMC sample size for $\mathrm{CL} / \mathrm{P}$ is three times bigger than the sample size in the Italian studies but data were collected during a period 
Vieira AR, Romitti PA, Orioli IM, Castilla EE. Complex segregation analysis of 1,792 cleft lip and palate families in South America: 1967-1997. Pesqui Odontol Bras 2003;17(2):161-5.

TABLE 3 - Parameter estimates and model-fitting from segregation analysis of CL/P families.

\begin{tabular}{c|c|c|c|c|c|c|c}
\hline Parameters & GT & NTF & NML & $\begin{array}{c}\text { SML } \\
\text { general }\end{array}$ & $\begin{array}{c}\text { SML } \\
\text { dominant }\end{array}$ & $\begin{array}{c}\text { SML } \\
\text { additive }\end{array}$ & $\begin{array}{c}\text { SML } \\
\text { recessive }\end{array}$ \\
\hline $\mathrm{q}$ & 0.85 & {$[1]$} & {$[1]$} & 0.85 & 0.37 & 0.67 & 0.77 \\
\hline$\tau(\mathrm{AA})$ & 0.77 & - & - & {$[1]$} & {$[1]$} & {$[1]$} & {$[1]$} \\
\hline$\tau(\mathrm{AB})$ & 0.22 & - & - & {$[0.5]$} & {$[0.5]$} & {$[0.5]$} & {$[0.5]$} \\
\hline$\tau(\mathrm{BB})$ & 0.01 & - & - & {$[0]$} & {$[0]$} & {$[0]$} & {$[0]$} \\
\hline$\beta(\mathrm{AA})$ & -0.35 & -1.5 & -0.5 & -0.5 & -1.5 & -1.5 & -1.5 \\
\hline$\beta(\mathrm{AB})$ & -1.5 & - & - & -1.5 & -1.5 & -1.25 & -1.0 \\
\hline$\beta(\mathrm{BB})$ & -3.0 & - & - & -1.0 & -1.0 & -1.0 & -1.0 \\
\hline$-2 \operatorname{lnL}$ & 142.00 & 255.34 & 144.35 & 154.75 & 254.25 & 246.91 & 238.40 \\
\hline LTR & - & 113.34 & 2.35 & 12.75 & 112.25 & 104.91 & 96.40 \\
\hline p value & - & $<0.001$ & 0.5 & $<0.001$ & $<0.001$ & $<0.001$ & $<0.001$ \\
\hline $\begin{array}{c}\text { No. parameters } \\
\text { estimated }\end{array}$ & 8 & 6 & 6 & 7 & 7 & 7 & 7 \\
\hline AIC & 166.00 & 275.34 & 164.35 & 180.75 & 278.25 & 270.91 & 262.40 \\
\hline \hline
\end{tabular}

GT, general transmission; NTF, non transmitted factor; NML, no major locus; SML, single major locus; q, gene frequency; [ ], parameters fixed by hypothesis in brackets; $\tau(\mathrm{AA}), \tau(\mathrm{AB}), \tau(\mathrm{BB})$, transmission probabilities; $\beta(\mathrm{AA}), \beta(\mathrm{AB})$, $\beta(\mathrm{BB})$, baseline parameters for types $\mathrm{AA}, \mathrm{AB}, \mathrm{BB}$; $\operatorname{lnL}, \log$ likelihood; LTR, likelihood-ratio test; AIC, Akaike's information criterion.

three times longer and they are not as geographically concentrated as the Italian data are. Results for inheritance of CL/P in Italy suggest a two-locus model with a major dominant locus and at least one modifier locus as the best model.

A no major locus model for $\mathrm{CL} / \mathrm{P}$ in a South American population is in concordance with previous studies done in the continent that reported evidence for a multifactorial model for $\mathrm{CL} / \mathrm{P}^{18}$. Because South American urban populations are not as racially stratified as, for instance, in the United States of America, individuals cannot easily be classified into discrete racial entities ${ }^{10}$. However, South American urban populations were shown to be largely Amerindian with different degrees of admixture, mainly African Blacks and Latin-European Caucasians ${ }^{16}$. Race is the only demographic variable that has been consistently associated with the prevalence of CL/P. Compared with Caucasians, the prevalence is higher in Asians (particularly Japanese) and lower in individuals of African descent $^{25}$. We believe genetic molecular studies may help to identify a discrete group under higher risk for $\mathrm{CL} / \mathrm{P}$.

A no major locus model is also in agreement with previous studies which showed a significant association between alleles of TGFA, MSX1, and TGFB3 and isolated CL/P in humans, either in some Caucasian ${ }^{2,3,15,20}$ and in South American populations $^{5,6,13,14}$.

\section{CONCLUSIONS}

South American populations represent a very interesting group for admixture mapping of oral clefts in humans, based on the disease frequency variation across ethnic groups, and a better understanding of the disease in the continent is very important for future studies. This report is the largest study to date of inheritance of CL/P in a South American population. Our results support that $\mathrm{CL} / \mathrm{P}$ has a complex genetic etiology, with an unknown number of loci that may vary markedly across populations, ethnic groups, and/or clefting phenotypes.

\section{ACKNOWLEDGEMENTS}

We are indebted to Jeff Murray for all his support. We also would like to thank Lina Moreno for many helpful discussions. Also Trudy Burns for useful insights, and Becky Schultz and Maria da Graça Dutra for helping with the manuscript. The results of this paper were obtained by using the 
Vieira AR, Romitti PA, Orioli IM, Castilla EE. Complex segregation analysis of 1,792 cleft lip and palate families in South America: 1967-1997. Pesqui Odontol Bras 2003;17(2):161-5.

program package SAGE, which is supported by a US Public Health Service Resource Grant (1 P41
RR03655) from the Division of Research Resources.

\section{REFERENCES}

1. Almeida ILB. Estudo genético-epidemiológico de fissura labial não-sindrômica no sudeste brasileiro. [Tese de Mestrado]. Curitiba: Universidade Federal do Paraná; 1997.

2. Ardinger HH, Buetow KH, Bell GI, Bardach J, VanDemark DR, Murray JC. Association of genetic variation of the transforming growth factor-alpha gene with cleft lip and palate. Am J Hum Genet 1989;45:348-53.

3. Beaty TH, Wang H, Hetmanski JB, Zeiger JS, Liang KY, Chiu YF, et al. A case-control study of nonsyndromic oral clefts in Maryland. Ann Epidemiol 2001;11:434-42.

4. Blanco R, Arcos-Burgos M, Paredes M, Palomino H, Jara L, Carreño $\mathrm{H}$, et al. Complex segregation analysis of nonsyndromic cleft lip/palate in a Chilean population. Genet Mol Biol 1998;21:139-44.

5. Blanco R, Jara L, Villaseca MC. Asociación entre la variación genética de MSX1 (Hox-7) y la fisura labiopalatina no sindrómica en población chilena. Rev Méd Chile 1998; 126:637-45.

6. Blanco R, Chakraborty R, Barton SA, Carreño H, Paredes $\mathrm{M}$, Jara L, et al. Evidence of a sex-dependent association between the MSX1 locus and nonsyndromic cleft lip with or without cleft palate in the Chilean population. Hum Biol 2001;73:81-9.

7. Booney GE. Regressive logistic models for familial disease and other binary trait. Biometrics 1986;42:611-25.

8. Carter CO. Genetics of common disorders. Br Med Bull 1969;25:52-7.

9. Castilla EE, Lopez-Camelo JS. The surveillance of birth defects in South America. I. The search for time clusters: epidemics. In: Obe G. Advances in mutagenesis research. Berlin: Springer-Verlag, 1990. p. 191-210.

10. Castilla EE, Lopez-Camelo JS, Campaña H. Altitude as a risk factor for congenital anomalies. Am J Med Genet 1999;86:9-14.

11. Christensen K; Mitchell LE. Familial recurrence-pattern analysis of nonsyndromic isolated cleft palate - a Danish registry study. Am J Hum Genet 1996;58:182-90.

12. Clementi M, Tenconi R, Collins A, Calzolari E, Milan M. Complex segregation analysis in a sample of consecutive newborns with cleft lip with or without cleft palate in Italy. Hum Hered 1995;45:157-64.

13. Jara L, Blanco R, Chiffelle I, Palomino H, Carreño H. Association between alleles of the transforming growth factor alpha locus and cleft lip and palate in the Chilean population. Am J Med Genet 1995;57:48-551.
14. Jara L, Blanco R, Chiffelle I, Palomino H, Carreño H. Evidence for an association between RFLPs at the transforming growth factor alpha (locus) and nonsyndromic cleft lip/palate in a South American population. Am J Hum Genet 1995;56:339-41.

15. Lidral AC, Romitti PA, Basart AM, Doetschman T, Leysens NJ, Daack-Hirsch S, et al. Association of MSX1 and TGFB3 with nonsyndromic clefting in humans. Am J Hum Genet 1998;63:557-68.

16. Lopez-Camelo JS, Orioli IM. Heterogeneous rates for birth defects in Latin America: hints on causality. Genet Epidemiol 1996;13:469-81.

17. Melnick M, Bixler D, Fogh-Andersen P, Conneally PM. Cleft lip+/-palate: an overview of the literature and an analysis of Danish cases born between 1941 and 1968. Am J Med Genet 1980;6:89-97.

18. Menegoto BG. Epidemiologia e interação herançaambiente nas fissuras labiopalatinas. [Tese de Mestrado]. Porto Alegre: Universidade Federal do Rio Grande do Sul; 1989

19. Mitchell LE. Genetic epidemiology of birth defects: Nonsyndromic cleft lip and neural tube defects. Epidemiol Rev 1997;19:61-8.

20. Mitchell LE. Transforming growth factor alpha locus and nonsyndromic cleft lip with or without cleft palate: a reappraisal. Genet Epidemiol 1997;14:231-40.

21. Murray JC. Face facts: genes, environment, and clefts. Am J Hum Genet 1995;5:227-32.

22. Orioli IM, Vieira AR, Amorim MR, Castilla EE. Feasibility of using molecular genetic tools in a congenital malformation registry. Frontiers Fetal Heath 2001;3:221.

23. Palomino H, Cerda-Flores RM, Blanco RM, Palomino HM, Barton SA, Andrade M, et al. Complex segregation analysis of facial clefting in Chile. J Craniofac Genet Dev Biol 1997; 17:57-64.

24. Sorant AJM, Bonney GE, Elstron RC, Bailey-Wilson JE, Wilson AF. SAGE Statistical analysis for genetic epidemiology. Release 2.2. Program available from the Department of Epidemiology and Biostatistics, Case Western Resource University, Cleveland, 1994.

25. Vanderas AP. Incidence of cleft lip, cleft palate, and cleft lip and palate among races: a review. Cleft Palate-Craniofac $J$ 1987;24:216-25.

26. Wyszynski DF, Beaty TH, Maestri NE. Genetics of nonsyndromic oral clefts revisited. Cleft Palate-Craniofac $\mathrm{J}$ 1996;33:406-17.
Recebido para publicação em 15/04/02 Enviado para reformulação em 22/10/02 Aceito para publicação em 27/03/03 